\title{
BIO-PESTISIDA BERBASIS EKSTRAK TEMBAKAU DARI LIMBAH PUNTUNG ROKOK DAN KULIT JERUK
}

\author{
Oleh : \\ Neti Kesumawati, Suryadi, Hasanawi Masturi \\ (Dosen Program Studi Agroekoteknologi dan Agribisnuis Fakultas Pertanian UMB) \\ Email : kesumawatineti30@gmail.com
}

\begin{abstract}
ABSTRAK
Limbah rokok atau yang sering kita sebut " Puntung rokok " adalah limbah yang tidak bermanfaat bagi lingkungan. Sedangkan limbah rokok dari tahun ketahun semakin meningkat, apalagi Indonesia merupakan negara peringkat ketiga dalam hal mengkonsumsi rokok. Menurut WHO, konsumsi rokok Indonesia perkapita adalah 1.742 rokok perorang pertahun. Rokok ini menghasilkan limbah berupa puntung rokok yang dapat merugikan lingkungan. Selain berdampak negatif bagi lingkungan, puntung rokok yang mengandung senyawa eugenol dapat digunakan untuk mengendalikan organisme penganggu tanaman (OPT). Kemampuan pestisida puntung rokok ini akan bertambah dahsyat dalam pengendalian OPT apabila dicampur dengan ekstrak kulit jeruk yang dianggap masyarakat sebagai sisa produk yang tidak bermanfaat dan bernilai, termasuk masyarakat Desa Perbo Kecamatan Curup Utara. Padahal daerah ini merupakan daerah penghasil jeruk sehingga sangat mudah dan banyak untuk mendapatkan kulit jeruk sebagai bahan baku pembuatan pestisida yang berguna untuk membasmi hama. Salah satu pestisida yang digunakan untuk membasmi hama dengan kemungkinan tidak menimbulkan dampak negatif bagi tanaman dan lingkungan, yaitu dengan menggunakan pestisida botani yang berasal dari tumbuh-tumbuhan, seperti kulit jeruk nipis. Berhubung masyarakat Desa Perbo Kecamatan Curup Utara masih lebih memprioritaskan pemakaian pestisida kimia dalam pengendalian OPT dan kurang memahami dampak negatif yang ditimbulkan, seperti timbulnya berbagai penyakit yang menyerang manusia serta terjadinya pencemaran lingkungan (Kesumawati, 2017). Maka perlu merubah pola pikir masyarakat agar beralih pada pestisida alami Cara yang paling efektif yang bisa diterapkan adalah melakukan penyuluhan/ pelatihan, dimana metodenya terdiri dari : (1) Pendidikandan penyuluhantentang perlunya memelihara kelestarian lingkungan dan bagaimana teknik pembuatan biopestisida kulit jeruk/puntung rokok; (2) Pelatihan cara pembuatan biopestisida yang bahan bakunya kulit jeruk dan puntung rokok. Kegiatan pengabdian yang dilakukan telah berhasil meningkatkan wawasan petani dalam membuat biopestisida campuran kulit jeruk dan puntung rokok, menekan biaya operasional dalam berusahatani serta meminimalisir pencemaran lingkungan akibat pemakaian pestisida sintetik.
\end{abstract}

Kata Kunci : Kulit jeruk, puntung rokok, pestisida nabati. 


\section{PENDAHULUAN}

\subsection{Latar Belakang}

Desa Perbo Kecamatan Curup Utara terkenal sangat subur sehingga banyak masyarakat di daerah ini bermatapencaharian sebagai petani. Banyak sekali produk-produk pertanian yang berasal dari daerah ini, salah satunya jeruk. Tetapi dewasa ini, lahan-lahan pertanian sudah banyak tercemar bahan kimia akibat masyarakat petani lebih memprioritaskan pemakaian bahan kimia dalam berusahatani, seperti pestisida kimia. Mereka lebih mengutamakan pertumbuhan ekonomi tanpa mengindahkan kelestarian lingkungan, dimana lahan-lahan pertanian dijadikan sebagai alat pemenuhan kebutuhan mereka. Prinsif hidup seperti inilah yang merupakan cikal bakal rusaknya lahan-lahan pertanian di sekitar Kecamatan Curup Utara. Walaupun demikian, pemakaian pestisida sintetik di daerah ini semakin merajalela, bahkan dianggap sebagai dewa penyelamat dalam usaha bercocok tanam. Hal terlihat dari perilaku masyarakat petaninya yang memanfaatkan produk ini tanpa memperhatikan batas ambang ekonomi keberadaan hama penyakit (Kesumawati, 2017). Oleh karena itu, perlu usaha untuk mengurangi ketergantungan masyarakat, seperti penggunaan ekstrak kulit jeruk yang memimiliki bahan aktif insektisida, minyak atsiri, limonoid dan saponin yang merupakan racun bagi saluran pencernaan hama (Kasi, 2013). Cara kerja pestisida kulit jeruk akan semakin baik apabila dicampur dengan puntung rokok yang merupakan sisa para perokok yang sangat sulit terdaur, dimana didalamnya masih terdapat sisa-sisa zat yang terkandung dalam rokok seperti nikotin dan eugenol.

Pestisida campuran kulit jeruk dan puntung rokok dirasa sangat cocok dan sesuai dengan kelestarian alam di Desa Perbo Kecamatan Curup Utara yang semakin hari kian tercemar. Selain tidak menimbulkan kekebalan terhadap hama dan penyakit serta OPT yang lain, pestisida alami ini sangat aman bagi lingkungan sekitar, bahan bakunya dapat dijumpai dengan mudah di daerah ini, pembuatannya cukup sederhana dan tidak membutuhkan biaya (Purnama, 2013). Oleh karena itu, apabila limbah-limbah ini dimanfaatkan secara maksimal dalam pembuatan biopestisida akan mengurangi biaya usahatani karena tidak perlu mengeluarkan biaya untuk membeli pestisida sintetik (Kesumawati, 2017).

Berdasarkan permasalahan di atas, perlu dilakukan penyuluhan dan pelatihan pembuatan pestisida campuran kulit jeruk dan puntung rokok bagi masyarakat petani di Desa Perbo Kecamatan Curup Utara yang diwakili oleh kelompok wanita tani (KWT) “ Mawar " Para anggota ini diharapkan menjadi informan kunci untuk petani lainnya. Pelatihan ini bertujuan untuk meningkatkan pengetahuan dan keterampilan dalam membuat pestisida campuran kulit jeruk dan puntung rokok. Selain itu, pembuatan pestisida ini secara teknis mudah dan murah sehingga dapat menekan biaya operasional para anggota KWT tani dalam bercocok tanam nantinya. Disamping itu, pelatihan ini dapat meningkatkan wawasan anggota KWT, khususnya dan masyarakat petani umumnya tentang arti penting menjaga kelestarian lingkungan melalui pertanian yang ramah lingkungan yang lebih mengandalkan bahan-bahan alam dalam kegiatan bercocok tanam (Nurzaman, dkk. 2011).

\subsection{Rumusan Permasalahan}

a. Pemakaian pestisida berbahan kimia telah menimbulkan berbagai penyakit bagi kehidupan manusia

b. Pemakaian pestisida berbahan 
kimia telah menimbulkan pencemaran bagi lahan-lahan pertanian khususnya dan lingkungan pada umumnya.

c. Pengetahuan dan ketrampila masyarakat petani, khususnya anggota KWT Mawar masih sangat minim dalam memanfaatkan limbah kulit jeruk dan puntung rokok menjadi biopestisida masih sangat minim

\section{METODE PELAKSANAAN}

\subsection{Solusi Permasalahan Kelompok Wanita Tani Mawar}

Dewasa ini, pestisida kimia bagi masyarakat petani, khusunya KWT Mawar di Desa Perbo merupakan produk yang sangat dibutuhkan dalam mengendalikan OPT. Bayangan gagal panen telah memaksa mereka menggunakan pestisida kimia tanpa mempertmbangkan batas ambang keberadaan hama. Kondisi ini akhirnya memperparah kerusakan lahan-lahan pertanian yang merupakan tumpuan untuk melanjutkan kehidupan. Sebenarnya permasalahan ini bisa diatasi dengan cara mengalihkan pemakaian pestisida kimia kepada pestisida yang memanfaatkan kulit jeruk dan puntung rokok yang banyak dijumpai di lingkungan sekitar. Kurangnya informasi yang diterima para anggota KWT membuat mereka memandang limbah sebagai hal menjijikkan. Oleh karena itu, perlu merubah cara pandang para anggota KWT tersebut melalui penyuluhan dan pelatihan, berupa sentuhan teknologi yang mudah, murah, mudah dilaksanakan dan berbasis pada potensi lokal.

\subsection{Bentuk Kegiatan}

Kegiatan pengabdian masyarakat dilaksanakan pada kelompok wanita tani
Mawar Desa Perbo Kecamatan Curup Utara Kabupaten Rejang Lebong dari tanggal 6 s/d 8 Juli 2018. Pelaksanaan pengabdian masyarakat dilakukan dengan beberapa tahapan, sebagai berikut :

\section{a. Survei Potensi Desa Perbo}

Survey dilakukan untuk mengetahui potensi sumberdaya alam yang ada pada Desa Perbo sehingga pemilihan materi yang disampaikan dalam kegiatan pengabdiaan masyarakat bisa berbasiskan sumberdaya lokal. Selain itu, untuk mengupulkan data anggota kelompok wanita tani dan permasalahanpermasalahan yang dihadapi mereka.

b. Pendidikan dan Penyuluhan

Untuk menambah wawasan anggota KWT Mawar dilakukan melalui pendidikan dan penyuluhan tentang bagaimana mengolah limbah kulit jeruk dan puntung rokok menjadi biopestisida serta manfaat biopestisida ini bagi kelestarian lingkungan

c. Pelatihan

Agar anggota KWT Mawar dapat lebih memahami cara pembuatan biopestisida yang bahan bakunya limbah kulit jeruk dan puntung rokok

d..Pengaplikasian

Pada kegiatan ini, anggota kelompok wanita tani didampingi untuk mempraktekkan pemakaian biopestisida kulit jeruk dan puntung rokok pada lahan pertanian

3.3. Cara kerja pembuatan pestisida alami campuran kulit jeruk dan puntung rokok

Tabel 1. Bahan dan peralatan

NoAlat Bahan

1. Blender. Kulit jeruk 50 gr 
2.PisauPuntung rokok

150-250 gr

3. Baskom Air 1 liter

4 Niru

Sumber : Muharyan (2013)

Cara Kerja :

1. Siapkan tembakau dari puntung rokok 150-250 gram

2. Kemudian keringkan tembakau dari puntung rokoktersebut menjadi benarbenar kering dan terlihat perubahan warnanya

3. Haluskan tembakau kering tersebut sampai benar-benar halus

4. Masukkan bubuk tembakau tersebut ke dalam wadah plastik

5. Campurkan bubuk tembakau tersebut dengan air dengan dosis 150 gr bubuk : 11 air

6. Siapkan kulit jeruk $150 \mathrm{gr}$

7. Masukkan kulit jeruk ke dalam blender, ditambah $50 \mathrm{ml}$ air dan haluskan

8. Masukkan kulit jeruk yang sudah dihaluskan ke dalam campuran tembakau dan air yang dudah diendapkan selama 1 hari

9. Saring larutan tembakau dan kulit jerukdengan menggunakan saringan

10 Masukkan larutan ke dalam spray dan siap disemprotkan

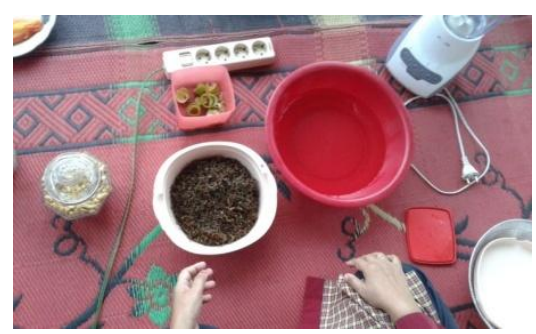

Gambar 1. Bahan-bahan biopestisida kulit jeruk + puntung rokok
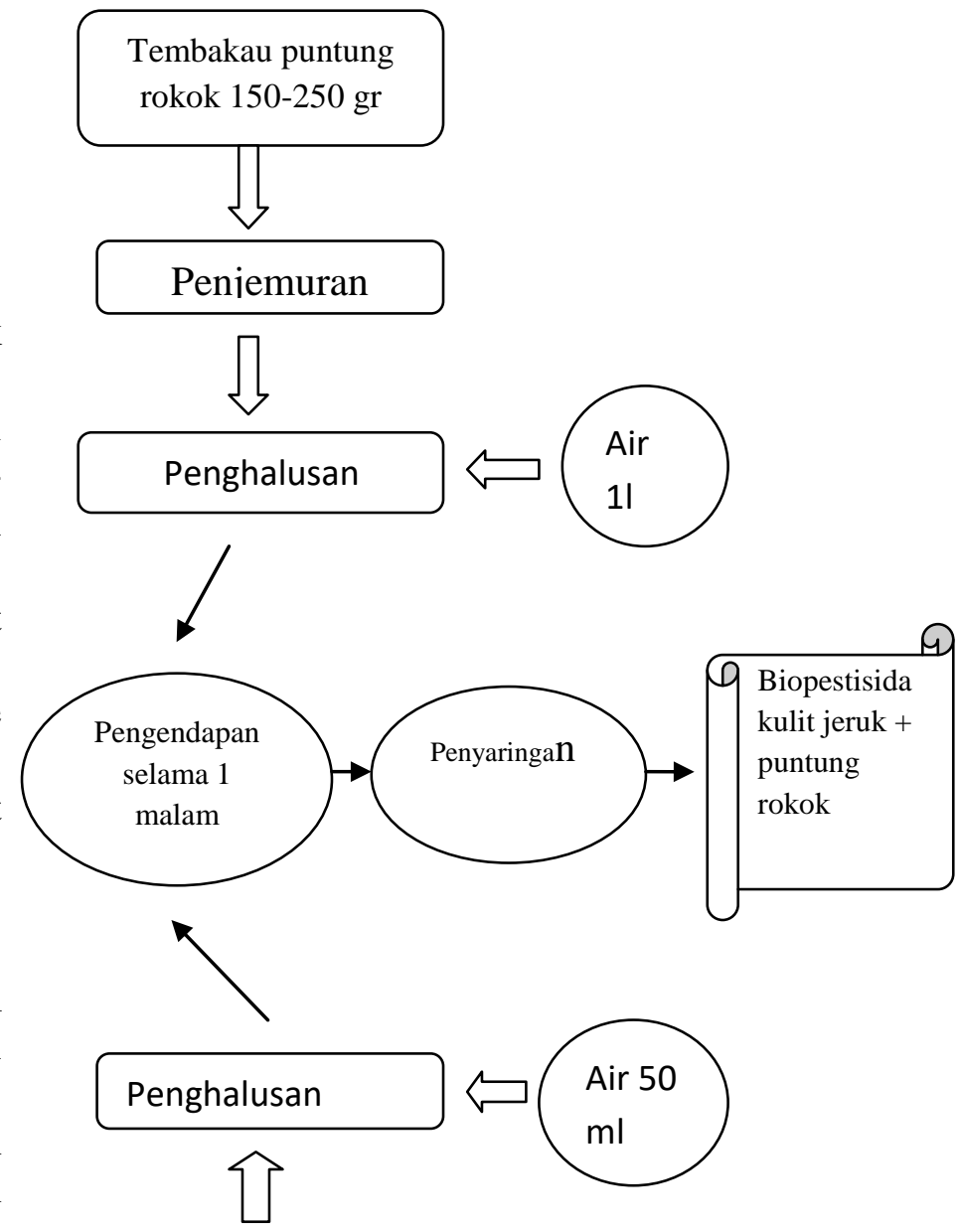

Kulit jeruk $100 \mathrm{gr}$

Gambar 2. Diagram alir pembuatan pestisida daun pepaya 


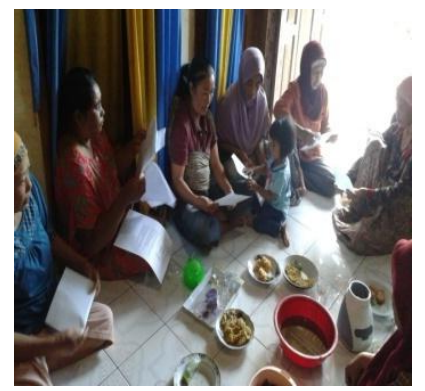

Gambar 3. Kegiatan penyuluhan

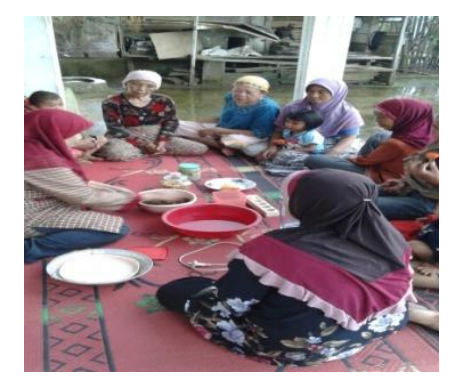

Gambar4. Pelatihan pembuatan biopestisida puntung rokok + kulit jeruk

\section{HASIL DAN PEMBAHASAN}

Kecamatan Curup Utara terletak di kaki Bukit Basah memiliki kesuburan tanah yang sangat cocok untuk usaha pertanian. Banyak sekali hasil-hasil pertanian yang berasal dari daerah ini, seperti buah jeruk. Buah jeruk dari daerah ini cukup digemari masyarakat karena rasanya yang manis. Banyaknya permintaan konsumen selaras dengan meningkatnya limbah kulit jeruk dan biasanya kulit jeruk ini dibuang begitu saja. Padahal kulit jruk bisa dijadikan sebagai bahan baku biopestisida yang cukup ampuh untuk mengendalikan organisme penganggu tanaman (OPT). Toana (2007), ekstrak kulit jeruk yang mengandung limolen dan linalool mempunyai daya bunuh terhadapseranggatanamanmisalnyatungau,lal atbuah,semut,jangkrikdanhamalainnya.
Kemampuan daya bunuh ini akan lebih meningkat kalau dikombinasikan dengan limbah putung rokok. Wiryadiputra (2003), pestisida dari tembakau berbahan aktif nikotin telah mampu mengendalikan hama serangga apids dan serangga berbadan lunak. Siswoyo, $d k k$, 2018tembakau dari limbah puntung rokok ini mempunyai potensi untuk dijadikan bio-pestisida untuk kegiatan pertaian yang ramah lingkungan.

Dewasa ini, para petani di Desa Perbo Kecamatan Curup Utara cukup kewalahan menghadapi serangan OPT pada tanaman yang dibudidayakan. Kegagalan panen akibat serangan OPT menjadi momok masyarakat petani di daerah tersebut sehingga keputusan penggunaan pestisida sintetik menjadi pilihan utama. Kerusakan lingkungan akibat penggunaan pestisida sintetik tidak menjadi pertimbangan mereka karena orientasi mereka adalah panen bisa berlimpah. Kalau cara berpikir seperti ini tidak dirubah akan berdampak pada menurunnnya kesuburan tanah, bahkan tanah menjadi tanah akhimya menjadi tandus.

Kondisi seperti di atas harus diantisipasi secepat mungkin dengan meengalihkan cara berpikir masyarakat petani yang lebih mengutamakan pemakaian pestisida sintetik menjadi pestisidaalami dengan memanfaatkan potensi lokal, seperti limbah kulit jeruk dan puntung rokok.

Keberadaan limbah puntung rokokdan limbah kulit jeruk di Desa Perbo belum dimanfaatkan dengan baik dan hingga saat ini hanya dibuang sebagai sampah.Atas dasar ini, melalui kesepakata antara Tim pengabdi yang terdiri Dosen Agroteknologi dan Agribisnis dengan para anggota KWT Mawar yang menjadi sasaran penyuluhan.pelatihan disepakatilah materi penyuluhan yang berjudul : "Pemanfaatan Limbah Kulit Jeruk dan Puntung Rokok Menjadi Biopestisida“. Dengan dimilikinya kemampuan serta keahlian dalam mengolah 
limbah-limbah ini diharapkan dapat mengendalikan OPT yang menyerang tanaman budidaya sehingga gagal panen terhindari dan bisa meningkatkan kesejahteraan masyarakat.

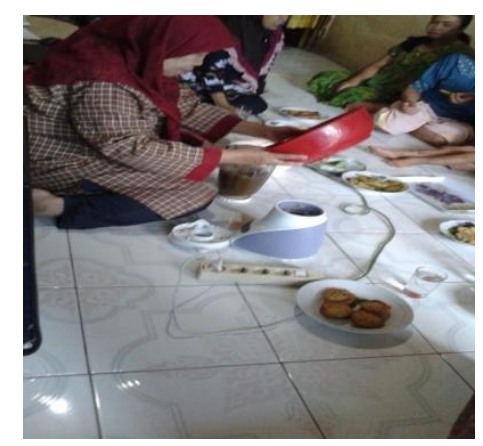

Gambar.4. Proses pembuatan biopestisida kulit jeruk + puntung rokok

Kegiatan ini diawali dengan penyuluhan kepada anggota KWT dan dilanjutkan dengan pelatihan dengan tujuan memberikan pengetahuan dan ketrampilan dalam membuat biopestisida campuran kulit jeruk dan puntung rokok. Selama kegiatan berlangsung, para anggota KWT mengikuti dengan antusias, hal ini bisa dilihat dari keaktifan mereka bertanya tentang pembuatan biopestisida tersebut. Hasil yang diperoleh dari pengabdian dikatagorikan cukup baik, yaitu

1. Anggota KWT Mawar dapat mengaplikasikan teknologi pengolahan limbah kulit jeruk dan puntung rokok menjadi biopestisida yang mempunyai kemampuan untuk mengendalikan OPT.

2. Terjadi peningkatan cara pandang anggota KWT Mawar mengenai limbah-limbah yang ada di sekitar mereka, terutama kulit jeruk dan puntung, dimana mereka tidak memandang limbah-limbah sebagai hal yang menjijikkan

3. Terjadi peningkatan wawasan mengenai arti pentingnya menjaga kelestarian lingkungan

\section{KESIMPULAN DAN SARAN}

\subsection{Kesimpulan}

a. Kegiatan penganbidian masyarakat di Desa Perbo Kecamatan Curup Utara Kabupaten Rejang Lebong berjalan sukses

b. I Pengetahuan dan ketrampilan anggota KWT Mawar meningkat setelah mengikuti penyuluhan dan pelatihan dalam pembuatan biopestisida campuran limbah kulit jeruk dan puntung rokok

C Para anggota KWT Mawar mampu mengaplikasikan teknologi pembuatan biopestisida campuran limbah kulit jeruk dan puntung rokok

\subsection{Saran}

Perlu penyuluhan dan pelatihan pembuatan biopestisida dengan berbagai bahan dasar yang ada di lingkungan sekitar, seperti daun sirsak, kulit cengkol, daun pepaya, dll

\section{DAFTAR PUSTAKA}

Kasi, P.D. 2013. Pemanfaatan Ekstrak Daun Jeruk Nipis (Citrus aurantifolia) Sebagai Insektisida Nabati Terhadap hama Walang Sangit (Leptocorisa oratorius) Pada Tanaman Padi. Program Studi Biologi, Fakultas MIPA Universitas Cokroaminoto Jurnal Dinamika, April 2012, halaman 12 - 18 ISSN 2087 - 7889 Vol. 03. No. 112 
Kesumawati, N. 2017. Biopestisida Daun Pepaya. Laporan pengabdian masyrakat. Fakultas pertanian Universitas Muhammadiyah Bengkulu

Muharyan; Alawiah, N; dan Yosefa M.I.A. 2013. Pemanfaatan Limbah Tembakau Dan Kulit Jeruk Sebagai Pestisida Nabati Yang Ramah Lingkungan. Sekolah Menengah Kejuruan Doa Bangsa Pelabuhan Ratu

Mursiah. 2013. Studi Pestisida Botani Kulit Jeruk Nipis (Citrus Aurantifolia Swingle) Terhadap 2 Jenis Belalang. Program Studi Manajemen Hutan Jurusan Manajemen Pertanian Politeknik Pertanian Negeri Samarinda

Purnaman, B.N; Safitri, F.V dan Aulianafis, N. 2013. Efektifitas Limbah Rokok Sebagai Insektisida Alami Yang Ramah Lingkungan. Universitas Dian Nuswantoro Semarang

Siswoyo, E; Masturah, R; dan Fahmi, N. 2018. Bio-Pestisida Berbasis Ekstrak Tembakau Dari Limbah Puntung Rokok Untuk TanamanTomat(Lycopersicuesc

$\begin{array}{llr}\text { ulentum) Jurusan } & \text { Teknik } \\ \text { Lingkungan. Fakultas } & \text { Teknik } \\ \text { Sipil dan } & \text { Perencanaan. } \\ \text { Universitas Islam }\end{array}$

Suharti, W.S; Wachjadi, M; Rahayuniati, R.F. 2010. Keefektifan Puntung Rokok Sebagai PengendaliGloeosporium fructigenum Pada Buah Apel (Efectivity Of Cigarette Butts As Control Agent Of Gloeosporium On Apple). Fakultas Pertanian Universitas Jenderal Soedirman, Purwokerto. Jurnal Pembangunan Pedesaan Volume 10 Nomor 2, Desember 2010, hal. 77-85

Toana, H. 2007. Pengaruh Konsentrasi Ekstrak Kulit Jeruk Nipis (Citrus aurantifolia S.) Pada Tanaman Kubis. Jurusan Hama dan Penyakit. Fakultas

Pertanian. Universitas Tadulako. Palu Jurnal Agroland14(3):195200,September2007. ISSN:0854-641

$\mathrm{X}$

Wiryadiputra, S. 2003. Keefektifan Limbah Tembakau Sebagai Insektisida Nabati untuk Mengendalikan Hama Helopeltis sp. pada Kakao. Jurnal Perlindungan Tanaman Indonesia, vol. 9, No. 1, 2003; hal 35-45 